\title{
5 \\ Growing or Perishing? The Development of Labour NGOs
}

\author{
Chun-Yi Lee
}

It is not easy to set up non-governmental organizations (NGOs) in China. They have to register with the government and, for a long time, the government subjected them to a complicated qualification system. They could not register with the Ministry of Civil Affairs (MoCA) directly. They had to get sponsorship from a suitable 'business supervision unit' within the government ('业务主管单位') and only then, once they had a sponsor, were they allowed to register with MoCA. Many NGOs were unable to find a suitable sponsor, so could not register with the government. This double filter definitely impeded the development of NGOs in China. They had to turn into underground organizations without any legal status, but they still functioned.

This situation has changed, though not necessarily to a more favourable one for labour NGOs. On 1 January 2012, the Guangzhou municipal government removed a major administrative hurdle for eight types of NGO seeking official registration. The government extended its so-called 'deregulation of social organizations' to Guangdong province on 1 July 2012 and now labour NGOs can register directly with MoCA without seeking the sponsorship of a 'business supervision bureau'. Undoubtedly, this facilitated government supervision of NGOs, but then most labour NGOs also wish to 'come out from underground'. Nonetheless, while society is relieved that the government has adopted a more open attitude towards NGOs, there are some signs that the government is failing to meet the expectations of society.

This chapter is about labour NGOs in China and the struggles they faced in July and August 2012. The main focus is on the crashing down of labour NGOs in the southern industrialized cities of Guangzhou and Shenzhen. Theoretically, I start with the ongoing debate about whether or 


\section{Social Development NGOs}

not there is a civil society in China. I then go on to look at the role of labour NGOs in Chinese society. My aim is to paint a clear picture of how labour NGOs interact with three parties - the Chinese government (both local and central), the workers and their funders.

\section{Introduction}

It is important to note the difference in China between NGOs and labour NGOs, they are different phenomena; labour NGOs are dedicated to improving conditions for workers in China.

Why, one might ask, do labour NGOs still exist in the society if they cannot get legal status? My answer, which I derive from the founders of labour NGOs, is because the society needs them. However, we have to be cautious about society's needs, for when labour NGOs were forced to move out of their offices in the summer of 2012, the workers put up little resistance to the local authorities' clamp-down on their labour NGOs.

Many of the founders of labour NGOs in China were workers who had experienced unjust treatment in factories. Mr Huang (interview S1) told me in August 2011 that he had been a labourer in a factory but then lost two of his fingers in an accident at work. When the owner, who did not want to compensate him properly, fired him, he set about studying the relevant regulations and then sued the factory (successfully) for proper compensation. After this successful experience, Mr Huang established a small centre to serve his fellow workers. However, he did not have enough funds to work unpaid for long. The government was not happy with what he was doing and, without a proper office, he was unable to convince foreign foundations to invest in his venture.

Though Mr Huang's centre was unfortunately closed down, according to Lee and Shen, there are 30 labour NGOs in the major cities in China. ${ }^{1}$ Labour NGOs mainly focus on helping workers with legal information and providing them with cultural entertainment. Since most of them cannot register with the government under their real names, they either use other titles to register their organizations or else not register and remain on the government's 'black list'. 'Workers need us', Mr Zhang (interview S2), another founder of a labour organization said: 'we visit injured workers in hospital, provide them with places to go after their working lives have ended, give them computers to get on-line, or broadcast some movies. We are not doing anything illegal.'

By February 2012, some labour NGOs were already starting to feel pressure from the government. Their landlords cut off the electricity and water supplies to their rented offices and, as a result, some labour NGOs 
became homeless. ${ }^{2}$ The situation grew more serious in July and August 2012, when at least seven organizations were forced to shut down. This triggered a group of 140 scholars from the outside world to sign an open letter to the Guangdong municipality to express their grave concern over the Guangdong government's repression of grass-roots labour NGOs. ${ }^{3}$ The letter was sent in mid-August 2012, but on 30 August another grass-roots labour NGO in Shenzhen (called Little Grass) suffered a severe crackdown. On Weibo, the Chinese social media, an on-line video record ${ }^{4}$ showed a group of people circulating in front of the Little Grass office. A member of staff at Little Grass started to worry and called the police; another tried to hand out leaflets to this unfriendly group of people about only wanting to help workers. The police did not come, but some minutes later the group revealed themselves as gangsters and used violence to enter the Little Grass office, throw out office papers and destroy facilities. Finally, they locked the door of the Little Grass office leaving the staff members outside. The long-awaited police never arrived.

The Little Grass experience captured on this short video might reflect the situations of many other labour NGOs being forced to close down. Who are these gangsters who crack down on labour NGOs? Where were the police when the NGOs needed their protection? In computer games or dramas, at least there are good guys and bad guys, and in the end the good guys usually defeat the bad guys. However, in reality, the distinction is not that clear. If people lose trust in their government, they become more difficulty to govern, which cannot help a government's effort to create a harmonious society. Can labour NGOs improve workers' conditions?

\section{The debate on civil society in China}

\section{Conceptualizing civil society}

Civil society as a norm, as Kumar rightly noted, ${ }^{5}$ sounds good; it has a good feel to it; it has the look of a fine old wine, full of depth and complexity. However, fine old wines can make one lose one's ability to discriminate and one's clarity of purpose. Because the labour NGOs we are discussing here should, in principle, be 'civic' rather than commercial or governmental organizations, it becomes necessary to revisit the concept of civil society. Though many would argue that some labour NGOs align themselves closely with government and others see their purpose as competing for financial support from foreign funding bodies, I shall argue in the next section that bad things happened in China because of constraints from the Chinese government. Since in this chapter I aim to 


\section{Social Development NGOs}

explore the role of labour NGOs as a component of the relationship between civil society and the Chinese state, I shall start by reviewing the concept of civil society per se.

Civil society touches on the major themes of Western political thought. ${ }^{6}$ It should be in the public realm, yet private individuals constitute it; the crucial point is that civil society is a collective entity existing independently of the state. To be more precise, Kumar views civil society from three different perspectives. ${ }^{7}$ The first traces the concept to its classical origins at the end of the eighteenth century, which was when civil society was synonymous with the state or 'political society'. From this vantage point civil society represents the growth of civilization to the point when society became 'civilized' - hence the strong emphasis on citizenship, law and order.

The second perspective derives from Marx, who claims that 'civil society embraces the whole material intercourse of individuals within a definite stage of the development of productive forces. ${ }^{, 8}$ This is the stage when the bourgeoisie can establish an economy that is distinct from the state and other regulatory bodies. In other words, Marx was arguing that members of the middle-class would acquire the economic means to support themselves independently of the state and be able to form a public arena of their own.

The third perspective, which Kumar borrowed from Gramsci, holds that civil society is indeed not found in the sphere of production or of economic organization, but in the state. 'Gramsci saw the separation of powers as a product of the struggle between civil society and political society in a given historical period. He argued that civil society would be unable to have power of its own, even in a liberal society, that all posts are elective; they are all organs of political hegemony. ${ }^{10}$ For Gramsci, civil society is the sum of the state and political society. The hegemony of a ruling class is expressed through the 'organic relations' between the two realms. ${ }^{11}$ How should we understand the term 'organic relations'? Bieler and Morton explain that only ideas that are connected to a particular constellation of social forces, which are internally related to the material, are significant. Only those ideas 'organize human masses, and create the terrain on which men move, acquire consciousness of their position' can be considered 'organic'. ${ }^{12}$ Extending Gramsci's ideology of civil society, a neo-Gramscian approach emphasizes an identifying social force created by the production process as the core collective actors to be investigated in class struggle. ${ }^{13}$ In other words, for neo-Gramscians it is crucial to look at the interrelationship between the social relations of production and the state to understand the interaction between the state and society. 
Gramsci perceived civil society as an arena in which the state attempts to persuade the exploited classes to accept the way society develops under capitalism as natural and legitimate. ${ }^{14}$ In other words, at suitable times or on certain occasions, the system or structure will use civil society to convince or coerce people into accepting and believing in the system that oppresses them. Institutions like the church, trade unions or schools can sometimes exercise various forms of hegemony. As Buttigieg, extending Gramsci's concept, argues, for the ruling group to be 'hegemonic', which means able to control political society with the consent of the governed, it must allow for a space that is, or at least appears to be, free of coercion. ${ }^{15}$ Civil society therefore is the space in which the state allows consenting citizens to form their thoughts under the ruling party's general direction. In other words, Gramsci and his followers negate the possibility of civil society having a free will; for them it is the safe state-built laboratory in which its citizens can play around with different experiments so long as they remain under the state's control.

According to Gallagher, there is a direct link between strengthening China's legal institutions and the party's interest in holding onto power. ${ }^{16}$ In other words, the legal system has become the tool through which the CCP legitimates its power, which relates to Gramsci's concept of hegemony. In the Chinese context, however, the rule of law is a doubleedged sword. As Gallagher explained, on the one hand it provides the government with a legitimate means of justifying its power, but on the other the law is very flexible in its implementation. How can the government justify the legal system if the implementation of the law rests on a shaky foundation? Yet, apart from sporadic complaints, the society rarely objects to the existence of this grey area.

Certainly, the advocates of civil society in central and eastern Europe have not accepted this rather passive perception of it. ${ }^{17}$ None of the three perspectives mentioned above - neither classical, Marxian nor Gramscian - addresses the invisibility of the state; on the contrary, they all focus on the different ways of disentangling the constant tug-of-war between the state and society. At heart, Solidarity was a movement for the self-defence and self-management of society in which the state was not challenged, but completely ignored. ${ }^{18}$ If we trace back to its classical origins, we can argue that civil society can contribute to development and change, for it is the arena in which individuals can unite and be emancipated from the tyranny of kings or authoritarian parties. The bonding of individuals, in other words solidarity, is the crucial element. ${ }^{19}$ However, the state is always there; the Polish experience failed to answer the question of what is left when 


\section{Social Development NGOs}

civil society is kicked out of the state. In other words, as Kumar remarked, Solidarity lacked an account of its ultimate political role. ${ }^{20}$ There are two parts to the relationship between the state and society, irrespective of whether or not the society is civil. Even if the society successfully manages self-governance, who will be in charge of the governing party? The civilians may elect another ruling party, but if we regard the governing party as the state, then it will never be possible to realize the Solidarity movement's dream of ruling out the state.

\section{Civil society in China}

Because the Solidarity movement called on the strength of civil society to change the regime, in the eyes of the Chinese government the term civil society is always tainted with rebellion. Indeed, 1989 was a significant year both for eastern Europe and China. The 1989 movement around Tiananmen Square inspired a few scholars to argue that the development of social organizations in China would initiate a change of China's partystate system. Furthermore, several argued that a demand from civil society could urge the state to change. ${ }^{21}$ The expectation that civil society would initiate dramatic change has not been realized because, after 1989, the Chinese Communist Party (CCP) so feared losing control that it tightened its grip in every sense. In October 1989, MoCA issued a document (No. 43) requiring all new social organizations both to register and to affiliate with a government body or official organization. The latter was to act as a supervisor or guardian within the bureaucratic system, thus allowing the party to reconfirm its control over those organizations. ${ }^{22}$ As I mentioned in the introduction to this chapter, this double filter certainly made it difficult for social organizations to operate legally in China and, since all of them were placed under the state's tight control, it eliminated any chance of civic society acting independently of the state.

The government tightened its control not only over the registration of social organizations but also over individuals' thoughts, especially among the intelligentsia. Intellectuals could enjoy limited freedoms so long as they behaved with political correctness and adhered to the 'four cardinal principles' Deng Xiaoping defined as Marxism-Leninism, socialism, party leadership, and people's democratic leadership. ${ }^{23}$ One can argue that after the 1989 Tiananmen Square movement, these four cardinal principles blindfolded Chinese intellectuals. As Beja put it:

Scholars and professors would be allowed to raise their academic level, to take part in symposiums and conferences aboard, to do 
research in [a] foreign university. But they would do so on condition they did not try to revive the organizations they had created in the 1980s, whose goal was to push for the transformation of the regime, and, obviously, that they not try to link with the disgruntled portions of the population to help them translate their discontent into political demands. ${ }^{24}$

Therefore, in discussing the development of civil society in China, it is difficult not to mention the support of the government from a positive perspective and surveillance from the government from a pessimistic one. Pei pointed out that the number of civic organizations increased dramatically in the 1990s. ${ }^{25}$ Nonetheless, an increase in numbers is only one gauge of the development of civil society and perhaps a superficial one as well. I hold a less positive view than Pei does about the equation between increasing numbers of civic organizations and the growth of civil society. However, it is important to note from Pei's work that there was a vibrant growth in interaction between social organizations and the state after the 1990s. Chinese scholars speak with different voices about the development of civic organizations in China. B. G. He, citing Chan, noted that 'Chinese autonomous organizations are neither completely autonomous from the state nor completely dependent on the state. ${ }^{26}$ He failed to elaborate on what kind of power relationship existed between the state and these social organizations that endured a semi-independent status. Others argue that social organizations have to gain political support from the state. ${ }^{27} \mathrm{Hsu}$ plainly stated that, in the Chinese context, civil society does not conform to its classical definition; it should be presented not as an opposing force against the state but as a negotiated space. ${ }^{28}$

After the 1990s, civic organizations, represented as civil society in China, had to align tightly with the state's support. As a result, quite a few scholars have adopted Schmitter's theoretical framework to analyse the development of civil society in China from the perspective of state corporatism. $^{29}$ Originating from fascist Italy's economic framework of 'corporate economy', Schmitter revived the concept after the Second World War and changed it to 'corporatism', which he detached from fascism to mean a 'system of interest representation'. The system is noncompetitive and hierarchical in a state society because the state has to authorize each unit in it. ${ }^{31}$ The development of civic organizations, especially labour NGOs, has the appearance of corporatism. However, I argue that, for two reasons, labour NGOs in China only have the appearance but not the essence of state corporatism. 


\section{Social Development NGOs}

Corporatists mainly see the society as an organic unit within which the institutional arrangements that link the organized interests of employers and the working class to the decision-making process of the state achieve class hegemony during economic development. ${ }^{32}$ It is a trade-off between the state and civic organizations. The state allows organizations to participate in policy decision making to increase its own legitimacy. In democratic corporatism, as Schmitter indicated, this exchange is more direct. In authoritarian states, the exchange between the state and civic organizations is more indirect and the nature of the exchange is different from that of democratic corporatism. ${ }^{33}$ Cox further explains that we can define state corporatism as the form of corporatism in production relations in which the state takes total control of the political leadership; in other words, state corporatism predominates over both management and labour without their being any effective counterweight through parliamentary control or accountability. ${ }^{34}$ The main point here, as Cox explains, is that both worker and employer organizations seek satisfaction mainly through direct relations with officials of either the state bureaucracy or the ruling political party. And, as Gallagher reminds us, cultivating clientelistic ties to party authorities is, for Chinese workers, a crucial aspect of getting by and improving their position in the factory. ${ }^{35}$ Peaceful labour relations are important to state corporatism because they serve the national interest.

In that they are forced, either by threats or enticements, to cooperate with the state, labour NGOs in China do not quite fit the model of state corporatism. The workers, the target groups of these NGOs, do not necessarily benefit from the labour NGOs' cooperation with the state. Also, by its nature, corporatism places an emphasis on institutional arrangements, yet the settings in which labour NGOs operate in China are not institutionalized. As I mentioned earlier, labour NGOs cannot even receive proper institutional recognition and, because they are scattered around various cities, there is no collective collaboration between different labour NGOs. Therefore, the relationship between the state and the development of labour NGOs in China bears only a shallow resemblance to state corporatism; its essence lies in a very different setting.

According to Gallagher, building the 'rule of law' in China is a state-led project. In fact, the rule of law is intended to be a substitute for more radical political change and to bring with it increased channels through which citizens can seek redress for their grievances and protect their legal rights. More importantly, it is also designed to legitimate the rule of the CCP as an institution that can both bring rapid economic growth and ensure social stability through the use of the law and courts. ${ }^{36}$ As Gallagher 
indicated, the whole state apparatus, that is the many governmental organizations, the National People's Congress, bureaucratic agencies, local government and the State Council, all actively engage in building the 'rule of law'.

\section{Historical review of the Chinese workers and the role of the All-China Federation of Unions (ACFTU)}

When the People's Republic China (PRC) was newly born in 1949, it declared itself a country that would fight for workers' rights and equity. At that time, Chinese workers were by and large a relatively privileged group within Maoist state socialism: they were a class that enjoyed stable, secure incomes, socially-provided housing, medical care, education, guaranteed lifelong employment, and social and political prestige. Nevertheless, the economic structure has changed dramatically since 1978 when China decided to rely on foreign direct investment (FDI) as its main source of economic development.

Quite a lot has been written about workers' protests at different moments in the PRC's history. ${ }^{37}$ Some of these scholars believe that the 1989 Tiananmen Square movement was especially significant to the Chinese labour movement because it gave rise to a totally independent labour union, the Beijing Workers' Autonomous Federation (gongzilan), being established in May 1989. Although gongzilan had a very short life, only until June 1989, its former members still campaign for Chinese labour rights from all over the world. ${ }^{38}$

Since the emergence and crackdown of gongzilan, a question that has intrigued scholars interested in Chinese labour studies has to be addressed. This is, are there any trade unions left to represent Chinese labourers?

The ACFTU, inaugurated in 1953, is the largest federation of trade unions in China, but it is a semi-official organization affiliated to the Chinese Communist Party (CCP). While many studies point to its impotence in representing Chinese workers, others argue that the ACFTU is incorporated into the party/state system by design - this is, in effect, 'corporative trade unionism'. ${ }^{39}$ Researchers have classified the ACFTU as an example of state-society corporatism, which means that in the relationship between the ACFTU and the state, the latter plays the overwhelmingly dominant role. ${ }^{40}$ If we retrace our steps back to the main definition of corporatism in the previous section, however, we see that corporatism, according to Schmitter, should be a 'system of interest representation'. More importantly, corporatists argue that corporatism is mainly about the trade-off between the state and civic organizations. From this vantage 


\section{Social Development NGOs}

point, the ACFTU is by no means a pure 'civic organization'; it is a semiofficial organization. In addition, there is no 'trade-off' between the ACFTU and the state; it only serves as a one-way 'transmission belt'. Theoretically, the ACFTU should act on behalf of the state to mobilize workers for more production on the one hand, while collecting workers' voices to report back to the state on the other. However, the latter function is rather superficial. ${ }^{42}$ As Howell indicated, the problem for the ACFTU is twofold: first, it is unclear who the ACFTU should represent, the workers or the party; and second, it is unclear how the ACFTU is supposed to represent a workforce as differentiated and diffuse as the one in China. ${ }^{43}$ Not only did the semi-official structure of the ACFTU weaken its voice before the state, but also the Tiananmen crackdown in 1989 further undermined its potential to act as an independent trade union. Chan claimed that the effect of the 1989 Tiananmen massacre was that the state tightened its control on any organized union, including the ACFTU, thus undercutting the union's traditional base in state enterprises. ${ }^{44}$ She argued that the national political leadership increasingly accepted privatization in the form of the reform of SOEs in the mid-1990s, labour flexibility, integration into the global market and the pursuit of economic development at the cost of equality. Under strong pressure from the government, the ACFTU gradually accepted this reality, while lower-level trade-union cadres had no concept of activist trade unionism. ACFTU officials had begun to understand their role as securing their own survival rather than protecting the interests of workers.

Since the ACFTU cannot represent the interests of all Chinese labourers and the wholly independent labour organization (gongzilan) was destroyed during the 1989 Tiananmen Square uprising, some scholars have started to ask why Chinese labourers failed to organize a collective movement to improve their status. China scholars have recently come up with various explanations for the observed patterns of sporadic contention, which include grievances, mobilizing structures, claims, tactics and targets of protest. $^{45}$

\section{Different types of labour NGOs in China}

In this section, I look at labour NGOs from four angles - legal status, founders, funding and the activities they provide.

\section{Legal status}

Because of the impediments to registering social organizations with the government introduced in 1989 , if they are to survive labour NGOs in 
China have had no option but to develop some basic counter strategies, of which there are three. ${ }^{46}$ The first is to collaborate with organizations with a clear legal status, for instance local trade unions, the Communist Youth League and academic institutions. By doing so, labour NGOs can carry out their projects in the name of their affiliates, yet retain autonomy over the actual work. This strategy bears some similarity to the government's double-filter mechanism for registering social organizations. The difference here is that the affiliation is with an academic institution rather than a government bureau. The second strategy, which is commonly seen in practice, is that the NGO registers itself as self-employed, an independent enterprise, or a limited company. Mr Jiang registered his organization as a commercial company. He told me:

I am using my company's resource to support my organization. What I really want to do is to provide workers with a platform to meet up with each other and even do some charity work for other minority groups during the weekend. Therefore, during the week days I focus on my 'company' but I will organize activities for workers during the weekend. ${ }^{47}$

Mr Jiang has two business cards, one for his commercial business and one for the workers. The third strategy is to choose not to register at all, which means going underground and keeping a low profile. However, the government is most likely to target this type of NGO and it is difficult for them to survive under government's surveillance.

\section{Founders}

Lee and Shen divided the founders of labour NGOs into two main categories - formal workers and concerned professionals. ${ }^{48}$ They then further divided the group of concerned professionals into journalists, academics and lawyers. ${ }^{49}$ From their thorough description of the three groups, it appears that the grand social structure somehow constrained the efforts of the concerned professional groups to help the workers, which takes us back to a previous argument about the Chinese intelligentsia. As Cheng $^{50}$ pointed out, there are different groups of Chinese intellectuals, of which some support labour NGOs, whereas there are others who compete among themselves for whatever power, interests and resources they can wrest from the state. Therefore, it is hardly surprising that a scholar from a well-known university in Guangzhou remarked that 'we do not do research on civil society, but we focus on good governance. ${ }^{51}$ While one 


\section{Social Development NGOs}

person's remark cannot represent the whole picture, it is more or less an indication of the government's tight control over the academic sector. Other professionals who wish to help workers face a similar scenario. The leader of the Institute for Contemporary Observation (ICO) in Shenzhen, Liu Kaming, is a journalist on the Legal Daily, has a doctoral degree in Chinese literature ${ }^{52}$ and has a very good relationship with the Shenzhen government. A famous labour-law firm, Laowei, charges low fees for labour lawsuits, promotes collective bargaining and provides training courses for labour organizations in the Shenzhen and Guangzhou areas. One lawyer from this company said: 'we are doing reform within the system; we do not want the system to collapse. ${ }^{53}$

Chen and Dickson argue that private entrepreneurs are the allies of the state, which is why one never sees private entrepreneurs in China joining the ranks of the middle class to fight for their interests against the state. The party state offers private businesses all sorts of opportunities to embed in the state, an embeddedness that provides privileged access not only to political decision making but also to more economic opportunities. ${ }^{54} \mathrm{I}$ argue that the mechanism of political embeddedness works as well for merchants and academics as it does for the state's closest ally, the private capitalist. From this point of view, the position of civil society in China is perhaps closest to Gramsci's notion that the "state" is equal to political society plus civil society, in other words hegemony protected by the armour of coercion' ${ }^{55}$ Here it is necessary to emphasize that the Chinese government both uses force to coerce and/or punish society and provides incentives to allow social sectors to submit willingly. To return to academia, the reason why most social scientists decide against writing about civil society is because it is not easy to get government funding for this kind of research and, consequently, such research papers are unlikely to be published in the top-ranking Chinese journals. The state does not 'punish' intellectuals as it did in 1989, but rather it coerces them away from undertaking research on sensitive topics.

My findings revealed that most leaders of labour NGOs in Shenzhen are former workers who had suffered unjust treatment at work, an unlawful dismissal or work injury for which they had been refused compensation, who decided to transform their personal experiences into organizing an institute to help their fellow workers. Their motive is simple. They feel solidarity with their fellow workers and do not want them to suffer the same injustice as they did. However, they need concrete resources to turn their good intentions into a reality. In fact, they need money and capable helpers, but most of them will not accept funds from government or 
enterprises because they are on 'the opposite side'. Some use their own savings to start the organization, ${ }^{56}$ most probably a one-person office to begin with, but this source is unsustainable. In the absence of other choices, they tend to turn to foreign funding bodies. Nevertheless, as I pointed out in the introduction to this chapter, Mr Huang found that, without a proper office or competent staff, foreign foundations are unwilling to donate money and a viscious circle sets in, which only goes to prove that it is difficult for an individual worker to organize a centre. Apart from financial resources, such a centre also needs management skills, legal expertise and the ability to negotiate with employers. To compensate for this shortfall, most worker-established organizations choose to work with an academic institution. For example, Yan-Yet Sen University in Guangzhou has set up a labour study centre as a platform for academics and practitioners. Laowei, the labour-law firm, works with a couple of labour NGOs in Guangzhou and Shenzhen to help handle their legal problems. The leader of a labour NGO in Shenzhen told me that it is difficult for workers to talk with those lawyers if they have need of a lawsuit. There is a gap between workers and lawyers. Therefore, our role is to be the middleman to help workers communicate with lawyers. ${ }^{57}$ However, this external help does not negate the need for properly-funded and capably-staffed labour NGOs.

\section{Funding}

If we examine Chinese NGOs from a strictly Western notion of what such an organization is, namely it has no association with government and does not aim to make profits, most probably very few labour NGOs in China would qualify as true NGOs. It might sound like a cliché, but NGOs in China have a Chinese character ${ }^{58}$ in that they derive their funding from government, from government-organized non-governmental organizations (GONGOs) and from foreign foundations.

GONGOs have complicated identities. Some argue that, despite their government funding, they can still serve society so long as they do not contravene any governmental rules. ${ }^{59}$ However, other scholars argue that, while government protection ensures their legitimacy and financial status, they will either intentionally or inadvertently sacrifice worker solidarity for the collective capacity of self-protection. ${ }^{60}$ The struggle over whether or not to accept government funds has probably existed for a long time. Nonetheless, since the crackdown on Shenzhen labour NGOs between June and October 2012, the harsh political atmosphere has exacerbated those NGOs' struggles. In June 2012, the leader of an NGO in Guangzhou told me that: 


\section{Social Development NGOs}

It is a difficult choice for us to consider whether to accept government help. For us, the important thing is to survive first. Some organizations stubbornly refuse to take government help, so they have to move out of their offices or have their electricity or water cut off. I cannot say we will take government help; the only thing I can say is that we weigh up our survival very carefully. ${ }^{61} \ldots$ The government's version is: if those organizations do not promote illegal activities, and it is so difficult to maintain an organization, why do they not accept government's purchasing funds? ?2 $^{6}$

Again we see echoes of Gramsci's idea that the state is equal to society. The Chinese state is ominous; if the government cannot reach every corner, it will purchase the service from one of these NGOs. ${ }^{63}$

If not funded by the government, most labour NGOs get their funding from a foreign foundation. As Lee and Shen indicated, because funds are scarce and unstable, labour NGOs often operate as a commercial market or industry, supported by the European Union, foreign governmental bodies, the ILO, the United Nations or even branding companies. ${ }^{64}$ One might assume that 'independent' labour NGOs funded by foreign foundations would have more courage than GONGOs to step over boundaries and initiate activities that raise the consciousness of workers. However, this assumption is not always well founded, for many foreign foundations deliberately avoid sponsoring projects they might consider politically incorrect or violating governmental policies. ${ }^{65}$ More importantly, NGOs that receive foreign funding are government targets. ${ }^{66}$ As I mentioned earlier, it is easy for a government to close down NGOs, but difficult for labour NGOs to obtain legal status; consequently, some of them do not register with the government and others register as commercial companies. The government can easily ban an NGO if its activities are inconsistent with its registered function. The fourth angle from which to view labour NGOs is the activities they provide for workers.

\section{Activities}

According to Chan, labour NGOs in China adopt either a community intervention approach or an enterprise intervention approach. ${ }^{67}$ The former offers the workers legal seminars on labour laws, legal information, computers with free internet access and movies at the weekends. In other words, they offer social activities with a view to promoting worker awareness of their legal rights, occupational health and safety and gender equality, in short, workers' right in general. Different scholars hold 
widely differing views about the effectiveness of these seminars. Lee and Shen $^{68}$ are highly critical of the labour-law training workshops that labour NGOs provide. They claim that the workers only attend them because the NGOs pay them $20 \mathrm{RMB}$ to do so, and $20 \mathrm{RMB}$ is more than their hourly wage. They also point out that the workers' feedback from these workshops is quite useless. Their observations raise some questions. Why is the law not implemented? Do the existing laws protect workers' interests and rights? ?9 $^{\text {9 }}$

Other scholars find the legal workshops extremely helpful and Froissart $^{70}$ positively lauded the labour NGOs' legal seminars on worker entitlement to overtime pay. The legal workshops will probably never answer the questions that Lee and Shen raised, mainly because those NGOs, and even their foreign funders, cannot really transgress sensitive boundaries. However, can we argue that the only reason to organize these seminars is to meet the funding body's requirement? My personal experience of a workers' centre in Shenzhen is that an understanding of worker rights gradually emerges from those 'not so relevant' seminars. As one of the organizers, a graduate from a leading Chinese university, told me: 'we have to know what the workers want. They have worked the whole week and, at the weekend, what we can provide to attract them to come over are those topics that really interest them. ${ }^{.71}$ These are not always about defending their rights; most of the time they are about making their leisure hours more interesting and meaningful. However, raising worker awareness is at the heart of all the seminars this centre provides. At some seminars, they discuss the role of trade unions, or speak about the workers' movements of other countries. After one of these seminars, a worker told me:

If it were not for these regular seminars organized by this centre, we would not think about trade unions, or we would not dare to discuss trade unions with other people. This centre is like a platform for us to meet and discuss issues with different people whom we do not easily meet in the factories. ${ }^{72}$

Those understandings and realizations certainly take a long time to mature in the workers' minds, but patience and tenacity are perhaps the best words to describe the spirit that drives these labour NGOs to run seminars for the workers.

The members of these community-based labour NGOs also visit injured workers in hospital and distribute leaflets outside factories about labour 


\section{Social Development NGOs}

law regulations and social security. As Chan mentioned, the outreaches of these events for workers are effective, ${ }^{73}$ though outdoor activities attract more government attention than indoor ones. Under some circumstances, local governments might try to take advantage of the NGO's work, at which point they adopt a neutral, defensible stance. ${ }^{74}$ For instance, they can rarely spare the manpower to visit injured workers. At a time when the political atmosphere was especially tense just before the eighteenth congress in November 2012, local officials put pressure on labour NGOs to avoid any possible disturbance of the status quo. Although Chan argued that moving to a different industrial zones was beneficial to NGO development, the NGOs decided to adopt a 'guerrilla strategy'. ${ }^{75}$ It is in fact very difficult for them to maintain worker solidarity if they have to move their offices to different localities from time to time. It takes time for workers to trust an institution; also, workers are ambivalent about legality and, to be on the safe side, usually shy away from attending the activities of what they might perceive as an illegal organization. Therefore, maintaining labour NGOs can be even more difficult than fighting a guerrilla war.

With his enterprise intervention approach, Chan provided another model of an NGO operation. ${ }^{76}$ Various branding companies put external pressure on the NGOs that Chan listed in his analysis, which are mostly based in Hong Kong or even abroad, to conduct in-factory audits and training. The only China-based organization to conduct in-factory audits or training was the Institute of Contemporary Observation (ICO), though to what extent the ICO can be called a labour NGO is difficult to say. It received funding from abroad and requests from branding companies to conduct in-factory audits, but it is closer to a corporate social responsibility (CSR) company than to a labour NGO. I believe that although audits and in-factory training are important for keeping up the pressure on factories to maintain a decent working environment, it is the other side of the coin from the workers' perspective. These labour NGOs might be important for consumers, but they have no direct contact with the workers.

\section{Civil society with restraints}

Can labour NGOs in China serve as a civil society? This question cannot be easily answered, even after having reviewed different types of labour organizations in China. In this section, I point out the difficulties that labour organizations face in China in the hope that it will improve our understanding of why there are so many restraints on labour NGOs interacting in civil society. 


\section{Lack of solidarity among labour NGOs}

Getting financial support and avoiding government pressure are the two essential constituents of NGO survival in China. With limited resources from foreign sponsors, fighting for financial support has become a major concern for most labour NGOs and, with such intense competition, it is difficult to build solidarity among them. ${ }^{77}$ Labour NGOs also suspect one another of having been 'bought off by the government, so are reluctant to share information. In February 2012, shortly before the recent crack-down started in the summer of 2012, a radical labour NGO, Dagongze, was expelled from its office. It started to visit other NGOs, not only in the Pearl River Delta but also in northern China and Beijing, in search of support. Its efforts were in vain and, one after the other, the local government in Shenzhen used violence to close down at least three more NGOs. Moreover, there is almost no contact between one NGO and another.

When I was conducting fieldwork in Shenzhen in May-June 2012, an NGO staff member called me up for information about another NGO I had just interviewed. That the staff member did not intend to visit or talk to the other NGO, but instead sought the information from a third party was an indication of the mistrust between NGOs. In early January 2013, the ICO invited ten grassroots NGOs in Shenzhen and Guangzhou to meet at its office to discuss the possibility of cooperation among them. During that meeting, all the NGO leaders spoke of how difficult they found it to get funding and to keep good staff. The ICO called the meeting because the Canadian consulate had a budget to fund Chinese labour organizations. The ICO was to serve as a bridge in the discussions about the fund and the Canadian representative attended the meeting. It is at least a positive sign that these labour organizations were able to discuss the funding application, but even so, the general feeling among them was that there is virtually no solidarity between them. The entrepreneurs, for instance, are much more united than the labour organizations because they have common interests to fight for that bind them together. Labour organizations have idealistic goals in common, such as worker solidarity, rights protection and the integration of migrant workers, ${ }^{79}$ but in reality they have conflicting interests. This fatal weakness allows the state to control them with ease.

\section{Lack of worker support}

After the summer of 2012, I went back to Shenzhen to observe the aftermath of the crack-down. It was not the first time the government had 


\section{Social Development NGOs}

suppressed labour NGOs. I wanted to witness the workers' response. Labour NGOs are designed to service the workers, so when the government closes down the institution, why is there no mass strike to express their discontent? Two interviewees provided their insights. One is a radical labour lawyer working at Laowei: ${ }^{80}$

All those foreign-funded labour NGOs were only organizing some social activities; they did not really respond to the central need of workers - workers' rights. Therefore, when the government crushed them, the workers did not care much because they thought they had only lost a place for socialization. In other words, in the future, only the type of NGO that promotes workers' movements will survive because workers will fight back if the government dared to crush them. This is because workers would feel that their interests and futures were tightly connected to the NGOs that promoted their rights, not to those that just organize social events.

When I asked another interviewee, who was on the staff of an NGO the government closed down at the end of September 2012, why the outside world had not seen the workers plead for their organization, she told me that:

When we were forced to leave our office, there was a small group of workers standing outside our office to support us. However, we told them to leave because we did not want to get them involved, or even cause them to be sent to prison. We just wanted to protect them. ${ }^{, 81}$

Whether it is because workers do not relate to NGOs very much or because NGOs want to protect them from governmental pressures, we do not hear workers' voices at the scene. From the workers' reactions to the crack-down of their labour NGOs, it is clear that the link between their strikes and labour NGOs is not strong. In other words, the role of labour NGOs in promoting a civic space for labour is very weak. Although workers organize strikes, they do not really seem to care about the position of NGOs, which suggests that the input of labour NGOs might be limited. Certainly, this is probably an overly superficial verdict, but I believe that only when labour NGOs can really motivate workers to the extent that they work for them as long-term volunteers, can we start to discuss whether labour NGOs can initiate a limited civil society in China. 


\section{Conclusion}

To return to the question of whether labour NGOs in China are growing or shrinking, I believe that it will depend on whether labour NGOs can represent workers and whether or not workers can see labour NGOs as serving their interests.

\section{Notes from the field}

\section{Note 1: What do you think of labour NGOs in China?}

I think now that the most important thing for Chinese workers in terms of industrial action is the legitimacy of strikes. The new labour contract law (promulgated in January 2008) does not clarify whether it is legal to strike. For most workers, it is important to know whether it is legal or illegal to participate in strikes. Equally, it is also important for workers to know whether labour NGOs are operating legally. At the end of the day, workers do not want to do 'illegal things' that will make them lose their jobs. However, the problem now in China, from a lawyer's perspective, is the grey zone of the legal system. If a substantial number of workers go on strike, then nobody will question the legitimacy of the strike. For instance, did anybody question the legitimacy of the famous Honda strike in 2010? No, because the number of workers on strike was enormous - almost 2000. Those employees were organized and determined, so their strike to demand a wage increase was successful. If we look at strikes in small factories, we see that managers or local officials often 'threaten' the workers by telling them that their strikes are 'illegal'. As a matter of fact, industrial action (or striking if you prefer) does not violate any Chinese law, but then Chinese law also does not permit or accept it. The labour contract law simply does not address this important issue. Can we therefore say that because it does not address the issue, organizing a strike is against the law? Coming back to my original point, I think that the legitimacy of industrial action, or of labour organizations in China, does not depend on the government's judgement because the government's verdict depends on the workers' willingness. In other words, it might sound illogical, but from my observation, if workers are 
determined enough and the number of people going on strike is large enough, the government will step back and try to negotiate with the workers. My conclusion is that, living in a society ruled by people and not the law, you have to be strong enough to stand your ground; you cannot depend on or trust a legal system with so many loopholes and grey areas.

Duan Y, labour lawyer at Laowei law firm

\section{Notes from the field}

\section{Note 2: What do you think of labour NGOs in China?}

I organized a small labour NGO from 2006 to 2010 . Before that I was a normal worker at a factory. I started to establish a labour NGO because I was injured at work. My job was to operate a big chopping machine; one day when I was working, I did not pay much attention and the machine chopped off two fingers on my left hand. I wanted the factory to pay my medical expenses, but the managers at the beginning were very reluctant; they did not want to be responsible for my injury. I was also confused, I thought they ought to pay me because I was injured at work, but I did not know how to ask them to do so. I decided to study the law by myself and I figured out the legal channel to negotiate with them. I did not take the case to court, yet I had a successful negotiation with the manager. After two years, I got full compensation for my medical expenses. After my own experience, I saw many of my co-workers face similar difficulties; we are the weak party in facing employers, and most of us do not know how to bargain with the employers when we have problems at work. It was for this simple reason that I decided to establish a worker's centre by myself to help my co-worker. However, I realized that personal willingness was not enough to establish a labour NGO. One needs funding to run a centre. At the beginning, I could receive some support from international foundations, but the situation deteriorated and it became more difficult for my small centre to get funding. The international organizations want to see a big clean office in which everything is 
organized, but I am only one person; it was difficult for me to get things done in an organized way with limited funding. It is like the chicken and egg problem. I needed more money to run an organized centre but because I did not have enough money to organize things in the centre, I lost the credit to get more funds from those international funding organizations. Quite apart from anything else, local officials always suspected I had some 'illegal dealings' with foreign foundations to mobilize workers. Meanwhile, I got married and we had a baby boy in 2009. My wife told me that, even if not for her but for our kid, I had to give up my job as a freelancer helping workers. I had to find a 'proper' job to raise our family. That was a very strong statement and I thought I had to listen to her. Therefore I closed down my small worker centre and started to find jobs at factories. However, because my reputation of helping workers 'deal with' their employers had spread around the neighbourhood, it was not easy for me to find a job at a factory; they saw me as a trouble maker. This is why, even now, I have not been able to get a stable job, I get some part-time jobs from time to time. Nevertheless, in my mind, I still wish, one day that I will be able to run a centre to help workers, I think this is my life-time dedication.

Huang Ming Ming, former organizer of a labour NGO, now in precarious jobs

\section{Notes from the field}

\section{Note 3: What do you think of labour NGOs in China?}

I do not think that those labour NGOs actually need to face such a difficult struggle. The government knows that workers have a lot of problems at work; we also want to help workers, as do those grassroots labour NGOs. Since our aims are the same, why do we not work together? Therefore, in Guangzhou, we persuaded labour NGOs to work with the government; we provided funding to those labour NGOs and we relied on their experiences to work with workers. I think their role is important and no governmental bureaux can replace them. We need these intermediate organizations 
between government and society. We (the government) certainly do not want to see those organizations work with international funding bodies; it is a very sensitive issue in the eyes of government that those organizations should receive international funds. Our logic is that if they need money to help workers, they can apply for government funding; we are very willing to help; they do not need to ask for money from aboard. We do not want to put those labour organizations in a difficult position; therefore we showed our utmost sincerity to work with them. As a matter of fact, many labour organizations in Guangzhou have already established a collaborative relationship with us; they have all made good progress so far. We hope to be more open to the society and learn from grassroots NGOs. There are a lot of misunderstandings about the government's attitude. I do hope in the long run that those labour NGOs, and more importantly workers, will be able to understand the government's position. The government does not want to have conflicts in the society; we hope by working with those labour NGOs to create a smooth industrial relationship.

Chen Wei-Guan, former chairman of Guangzhou city ACFTU

\section{Notes}

1. C. K. Lee and Y. Shen (2011) 'The Anti-Solidarity Machine? Labour Nongovernmental Organizations in China', in S. Kuruvilla, C. K. Lee and M. Gallagher (eds) From Iron Rice Bowl to Informalization: Markets, State and Workers in a Changing China (Ithaca, NY: Cornell University Press) p. 174.

2. Zhang Ziru, 'Guangdong NGOs Face Grand-scale Regulation: The Government is Using a Two-handed Policy, Suppression and Incorporation' (in Chinese), http://www.szwlg.org/news/lgnew/2012/0608/911.html, (accessed 3 September 2012).

3. Open Letter to Guangdong Government', http://sacom.hk/archives/953, (accessed 3 September 2012).

4. See www.56.com/u25/v_NzIxOTk2MTQ.html\#fromoutpvid=NzIxOTk2MTQ for the video link; however, it might have been taken off some time later (accessed 3 September 2012).

5. K. Kumar (1993) 'Civil Society: An Inquiry into the Usefulness of a Historical Term', The British Journal of Society, vol. 44, no. 3, pp. 375-95, at p. 376.

6. A. B. Seligman (1992) The Idea of Civil Society (New York: Macmillan) p. 3.

7. Kumar, 'Civil Society', pp. 376-82.

8. Karl Marx and Frederick Engels (1963) The German Ideology, edited by R. 
Pascal (New York: International Publishers) pp. 26-7, cited in Kumar, 'Civil Society', p. 377.

9. Kumar, 'Civil Society', p. 382.

10. A. Gramsci (1971) Selection from the Prison Notebooks (New York: International Publishers) pp. 245-6.

11. Kumar, 'Civil Society'.

12. Andreas Bieler and Adam David Morton (2008) REFERENCE MISSING, PLEASE SUPPLY, pp. 117-22, referenced from Andreas Bieler (2011) REFERENCE MISSING, PLEASE SUPPLY, p. 168.

13. Cox and Sinclair (1996) REFERENCE MISSING, PLEASE SUPPLY pp. 57-8; referenced from Bieler, REFERENCE MISSING, PLEASE SUPPLY (2011) p. 167.

14. J. Howell and J. Pearce (2001) Civil Society and Development: A Critical Exploration (Boulder: Lynne Rienner) p. 34 referenced from Gramsci, Prison Notebooks, p. 238.

15. Joseph Buttigieg (2005) 'The Contemporary Discourse on Civil Society: A Gramscian Critique', Boundary 2, vol. 32, no. 1, pp. 33-52, at p. 43.

16. M. E. Gallagher (2005) 'Use the Law as your Weapon', in N. J. Diamant, S. B. Lubman and K. J. O'Brien (eds) Engaging the Law in China (Redwood City, CA: Stanford University Press) p. 75.

17. Pelczynski (1988) REFERENCE MISSING, PLEASE SUPPLY, p. 362.

18. Kumar, 'Civil Society', p. 386.

19. Howell and Pearce, Civil Society and Development, p. 30.

20. Kumar, 'Civil Society', p. 387.

21. Chen (2012) p. 3 REFERENCE MISSING, PLEASE SUPPLY referenced from B. McCormick, S. Z. Su and X. M. Xiao (1992) 'The 1989 Democratic Movement: A Review of the Prospect of Civil Society in China', Pacific Affairs, vol. 65, no. 2, pp. 182-201; J. Howell (2000) 'Organising around Women and Labour in China: Uneasy Shadows, Uncomfortable Allies', Communist and PostCommunist Studies, vol. 33, no. 3, pp. 355-77; White et al. (1996) REFERENCE MISSING, PLEASE SUPPLY.

22. Howell and Pearce, Civil Society and Development, p. 134.

23. B. G. Guo (2003) 'Political Legitimacy and China's Transition', Journal of Chinese Political Science, vol. 8, nos 1-2, pp. 1-25, at p. 13, reference in W. W. Chang (1988) China under Deng Xiaoping: Political and Economic Reform (London: MacMillan Press) pp. 45-50.

24. J.-P. Beja (2006) 'The Changing Aspects of Civil Society in China', Social Research, vol. 73, no. 1, pp. 53-74, at p. 62.

25. M. Pei (1998) 'The Growth of Civil Society in China', in J. A. Dorn (ed.) China in the New Millennium (Washington, DC: Cato Institute) p. 248.

26. Chan, (2012) REFERENCE MISSING, PLEASE SUPPLY, p. 2, reference taken from B. G. He (1997) The Democratic Implication of Civil Society (New York: St Martin's Press) pp. 7-8.

27. Xu Ying and Ngan-Pun Ngai (2011) 'Moral Resources and Political Capital: 


\section{Social Development NGOs}

Theorizing the Relationship between Voluntary Service Organizations and Development of Civil Society in China', Nonprofit and Voluntary Sector Quarterly, vol. 40, no. 2, pp. 247-69, at pp. 258-212.

28. J. Y. J. Hsu (2012) 'Space of Civil Society: The Role of Migrant Nongovernmental Organisations in Beijing and Shanghai', Progress in Development Studies, vol. 12, no. 1, pp. 63-76, at pp. 65-6.

29. A. Chan (1993) 'Revolution or Corporatism? Workers and Trade Unions in post-Mao China', Australian Journal of Chinese Affairs, no. 29, pp. 31-61, at pp. 35-6; M. Pearson (1994) 'The Janus Face of Business Association in China: Socialist Corporatism in Foreign Enterprises', Australian Journal of Chinese Affairs, no. 31, pp. 25-36, at pp. 26-7; J. Unger (1996) 'Bridges: Private Business, the Chinese Government and the Rise of New Associations', China Quarterly, vol. 147, pp. 795-819, at pp. 795-6; J. Unger and A. Chan (1995) 'China, Corporatism and the East Asia Model', Australian Journal of Chinese Affairs, no. 33, pp. 29-53, at p. 31; G. White (1993), 'Prospect of Civil Society in China: A Case Study of Xiaoshan City', Australian Journal of Chinese Affairs, no. 29 , pp. 63-87, at pp. 68-9.

30. Spirito and Volpicelli were the leading theorists of the 'corporate economy', reference in Gramsci, Prison Notebooks, p. 257.

31. Chan, 'Revolution or Corporatism', p. 35, reference from P. C. Schmitter (1974), 'Still a Century of Corporatism?, in F. B. Pike and Thomas Stritch (eds) The New Corporatism: Social Political Structure in the Iberian World (Notre Dame, IN: University of Notre Dame Press) pp. 85-130.

32. Peter J. Williamson (1985) Varieties of Corporatism (Cambridge: Cambridge University Press, pp. 2-38) referenced in C. L. Huang (1995) 'State Corporatism in Question: Labour Control in South Korea and Taiwan', Chinese Political Science Review, vol. 28, pp. 25-48, at p. 27.

33. Huang, 'State Corporatism', p. 27.

34. Cox, (1987) REFERENCE MISSING, PLEASE SUPPLY, p. 80.

35. Gallagher, (2006) REFERENCE MISSING, PLEASE SUPPLY, p. 60.

36. Gallagher, 'Use the Law as your Weapon', p. 57.

37. Elizabeth Perry and Li Xun (1997) Proletarian Power: Shanghai in the Cultural Revolution (Boulder: Westview); Jackie Sheehan (1998) Chinese Workers: A New History (London: Routledge); Andrew Walder (1991) 'Popular Protest in the Chinese Democracy Movement of 1989', UCLA-CSA Working Papers, no. 6, June, pp. 467-92.

38. Walder and Gong, 1993, REFERENCE MISSING, PLEASE SUPPLY, 1-29

39. Chan, 'Revolution or Corporatism'; Wen Gong (2002) 'Chinese Trade Unions Committed to Protecting Workers', Chinese Trade Unions, no. 1, pp. 6-15; J. Howell (2003) 'Trade Unionism in China: Sinking or Swimming?' Communist Studies and Transition Politics, vol. 19, no. 1, pp. 102-22; Elizabeth Perry (1995) 'Labour's Battle for Political Space: The Role of Worker Associations in Contemporary China', in D. S. Davis, R. Kraus, B. Naughton and E. Perry (eds) Under Spaces in Contemporary China (Cambridge: 
Cambridge University Press) pp. 302-25; Walder, 'Popular Protest'.

40. G. White, J. Howell and X. Y. Shang (1996) In Search of Civil Society: Market Reform and Social Change in Contemporary China (Oxford: Clarendon Press) p. 28.

41. Schmitter, 'Still a Century'.

42. Chan, 'Revolution or Corporatism', pp. 36-7.

43. Howell, 'Trade Unionism in China', pp. 103-22.

44. A. Chan (2007) 'Realities and Possibilities for Chinese Trade Unions', in Craig Phelan (ed.) The Future of Organised Labour: Global Perspectives (Bern: Peter Lang) pp. 275-304, at p. 288.

45. Marc J. Blecher (2002) 'Hegemony and Workers' Politics in China', China Quarterly, vol. 170, pp. 284-303; Cai (2001), REFERENCE MISSING, PLEASE SUPPLY, 243-51; Cai Yongshun (2002) 'The Resistance of Chinese Laid-off Workers in the Reform Period', China Quarterly, vol. 170, pp. 327-34; Chen, 2003 REFERENCE MISSING, PLEASE SUPPLY; Hurst, 2004 REFERENCE MISSING, PLEASE SUPPLY; Hurst and O'Brien, 2002 REFERENCE MISSING, PLEASE SUPPLY; Lee, 2000 REFERENCE MISSING, PLEASE SUPPLY, 2002 REFERENCE MISSING, PLEASE SUPPLY; Solinger, 2000 REFERENCE MISSING, PLEASE SUPPLY

46. C. Chan (2013) 'Community-based Organisations for Migrant Workers' Rights: The Emergence of Labour NGOs in China', Community Development Journal, vol. 48, no. 1, pp. 1-17, at pp. 5-6, referenced from N. Pun (2008) 'The Making of a Global Dormitory Labour Regime: Labour NGOs and Workers Empowerment in South China', in R. Murphy (ed.) Labour Migration and Social Development in Contemporary China (New York: Routledge) pp. 154-70.

47. Interview $S 1$.

48. Lee and Shen, 'The Anti-Solidarity Machine', p. 173.

49. Ibid., p. 176.

50. X. N. Cheng (2002) 'The Division of Social Elites in Current Society' (dang jin shè huèi sìh pài jing ying jhih fen shu) http://www.politicalchina.org/print news.asp?newsid=178982 (accessed 29 April 2013).

51. Interview $\mathrm{G} 2$.

52. Lee and Shen, 'The Anti-Solidarity Machine', p. 176.

53. Interview $\mathrm{S} 4$.

54. J. Chen and B. J. Dickson (2010) Allies of the State: China's Private Entrepreneurs and Democratic Change (Cambridge: Harvard University Press, p. 38.

55. Gramsci, Prison Notebooks, p. 263.

56. Y. Huang (2010) Globalization and the Transformation of Chinese Labour Politics: Based on Observations in the South China Region (Shanghai: Shanghai People's Publishers) [In Chinese], pp. 128-41; Interview S1.

57. Interview S2b.

58. Q. Ma (2006) Non-governmental Organisations in Contemporary China (London: Routledge) pp. 8-9. 


\section{Social Development NGOs}

59. Ibid., p. 10.

60. Lee and Shen, 'The Anti-solidarity Machine', p.177.

61. Interview G3.

62. Interview G1.

63. Cheng et al., 2010: 1090.

64. Lee and Shen, 'The Anti-Solidarity Machine', p. 179.

65. Y. S. Cheng, K. Ngok and W. Zhuang (2010) 'The Survival and Development Space for China's Labour NGOs: Informal Politics and its Uncertainty', Asian Survey, vol. 50, no. 6, pp. 1082-106, at p. 1096; Interview S5.

66. Chan, 'Community-based Organisations', p. 6; Interview G1.

67. Chan, 'Community-based Organisations', pp. 7-13.

68. Lee and Shen, 'The Anti-Solidarity Machine', p. 184.

69. Ibid., p. 185.

70. C. Froissart (2006) 'Escaping from Under the Party's Thumb: A Few Examples of Migrant Workers' Striving for Autonomy', Social Research, vol. 73, no. 1, pp. 197-218, at p. 201.

71. Interview S6.

72. Interview $\mathrm{S} 7$.

73. Chan, 'Community-based Organisations', pp. 8-9.

74. Cheng, 'Survival and Development Space', p. 1090.

75. Chan, 'Community-based Organisations', p. 6.

76. Ibid., pp. 9-11.

77. Lee and Shen, 'The anti-solidarity machine', p. 180.

78. Ibid., p. 177.

79. Interview S8.

80. Interview S9.

\section{Interview data list}

G1 Mr Chen Wei-Guang, former chairman of Guangzhou ACFTU, Guangzhou, 14 December 2012.

G2Professor from Sun Yet-Sen University, Guangzhou, August 2011.

G3 Mr Jing, leader of Pearl River Delta Worker's Center, Guangzhou, June 2012.

S1 Mr Huang, former leader of Little Rain Drop, Shenzhen, 18 August 2011.

S2 Mr Zhang, Shenzhen, organizer of Spring Breeze, 23 May 2012.

S3 Mr Jiang, organizer of Green Grass, Shenzhen, 5 June 2012.

S4 Lawyer Meng, Laowei, Shenzhen, 22 January 2013.

S5 Dr Liu Kaming, leader of ICO, Shenzhen, 20 January 2013.

S6 Workers' centre at Tsinghu Library, Shenzhen, 9 December 2012.

S7 Workers' centre at Tsinghu Library, Shenzhen, 6 January 2013.

S8 Lawyer Duan, Laowei, Shenzhen, 4 December 2012.

S9 Female staff member, Hand in Hand Organization, Shenzhen, 23 January 2012. 